\title{
TV/Series
}

$6 \mid 2014$

Écho et reprise dans les séries télévisées (III) : de la métafiction à la transmédialité

\section{Game of Thrones: Quality Television and the Cultural Logic of Gentrification}

\section{Dan Hassler-Forest}

\section{(2) OpenEdition \\ Journals}

Electronic version

URL: http://journals.openedition.org/tvseries/323

DOI: $10.4000 /$ tvseries.323

ISSN: 2266-0909

\section{Publisher}

GRIC - Groupe de recherche Identités et Cultures

\section{Electronic reference}

Dan Hassler-Forest, "Game of Thrones: Quality Television and the Cultural Logic of Gentrification », TV/ Series [Online], 6 | 2014, Online since 01 December 2014, connection on 30 April 2019. URL : http:// journals.openedition.org/tvseries/323; DOI : 10.4000/tvseries.323

\section{(c) (i) (9)}

TV/Series est mis à disposition selon les termes de la licence Creative Commons Attribution - Pas d'Utilisation Commerciale - Pas de Modification 4.0 International. 


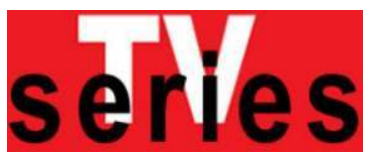

\section{Game of Thrones: Quality Television and the Cultural Logic of Gentrification}

Dan HASSLER-FOREST

The success of the television adaptation of Game of Thrones marks a crucial transitional moment in the relationship between cult audiences and the global élite associated with 'quality television'. By looking not only at the specific changes made to the novels as they were adapted for television, but also at the reception practices that have surrounded the series on fan forums and social media, this essay argues that the 'mainstreaming' of cult genres has troubling political implications. Increasingly, fan activity is in the process of being commodified by corporations that mobilize their most loyal consumers as brand-name ambassadors and online 'influencers'.

$\mathrm{I}$

$\mathrm{t}$ has become commonplace to proclaim that we live in a new Golden Age of television drama. Since the late 1990s, we have experienced a veritable deluge of serialized television narrative that is routinely compared (and often favorably) to the literary masterworks of Shakespeare, Dickens, Balzac, and Pynchon. HBO evangelists have proclaimed that the television series is already the dominant narrative form for the $21^{\mathrm{st}}$ century, as film had been for the twentieth, and the novel had been for the nineteenth ${ }^{1}$. Whether or not this kind of hyperbole is justified remains to be seen, but when the most frequently discussed question within a university's English literature department is no longer 'what book do you recommend?' but 'which series should I be watching?', it seems obvious that something has certainly changed.

Ironically, this transformation of television culture has occurred during the exact period in which television itself has in many ways experienced its demise: the medium's third era, in which its boundaries are challenged and reframed by the rise of digital culture and media convergence $^{2}$, is referred to as 'post-television' in the same way that its second era was 'post-network3'. In certain ways, the television medium

${ }^{1}$ Gary R. Edgerton and Jeffrey P. Jones, The Essential HBO Reader, Lexington, University of Kentucky Press, 2009.

2 Henry Jenkins, Convergence Culture: Where Old and New Media Collide, New York, New York University Press, 2006.

Catherine Johnson, "Tele-branding in TVIII: The network as brand and the programme as brand", in New Review of Film and Television Studies, Vol. 5, No. 1, 2007, p. 5-24.

3 Roberta E. Pearson, "Lost in Transition: From Post-Network to Post-Television", in J. McCabe and K. Akass (eds.), Quality TV: Contemporary American Television and Beyond, London, Tauris, 2007. 
therefore seems to be experiencing this Golden Age posthumously, though perhaps we should be careful before we proclaim yet another narrative medium officially deceased.

One of the most remarkable transformations in this period of widespread acclaim for certain kinds of new televisual content has been the prominence of fantastical genres. Long a fringe phenomenon within scripted television drama ${ }^{4}$, genres like fantasy, horror, and science fiction have played an increasingly dominant role in the development of $21^{\text {st }}$ century 'Quality TV': American network hits like Lost (ABC, 2002-2010) and Heroes (NBC, 2006-2010), basic cable phenomena like Battlestar Galactica (SyFy, 2004-2009) and The Walking Dead (AMC, 2010- ), and premium cable productions from Dead Like Me (Showtime, 2003-2004) to True Blood (HBO, 2008-2014) are among the most widely acclaimed serialized television narratives 5 . HBO's hit fantasy series Game of Thrones (2011- ) is not only the most successful exponent of this development, but it also demonstrates clearly how television's adaptation of the content, the forms, and the discursive practices of other media have resulted in its recent increase in cultural capital ${ }^{6}$. It adapts not only a series of novels that had developed a small but very devoted fan base, but also a larger set of aesthetic and discursive practices that relate back to the institutional framework of American premium cable and 'Quality TV.'

As a case study that illuminates some of the key transformations in serialized television drama, it therefore suits not only the framework of shifting hierarchies of adaptive value in the context of media convergence and globalization: the narrative's emphasis on political conflict in an imaginary world brings into sharp focus the relationship between fictional geopolitics and our own 'post-ideological' moment?. While the franchise's status as a global cross-media phenomenon constitutes its own politics of adaptation, the ideology reflected by its world-building process simultaneously makes up an illuminating adaptation of politics. The overwhelming success of the Game of Thrones brand thus provides us with a unique opportunity to study not only the ways in which the ongoing transformation of media culture has affected traditional methods of

4 Jason Mittell, Genre and Television: From Cop Shows to Cartoons in American Culture, Florence, Psychology Press, 2004.

5 While American productions remain the global norm for trends in serialized TV drama, recent European productions such as the British In the Flesh (BBC, 2013- ), British-Canadian coproduction Orphan Black (BBC America, 2013- ), and the French Les Revenants (Canal+, 2012- ) demonstrate that the interest in fantastical genres is not limited to US television.

${ }^{6}$ Pierre Bourdieu, Distinction: A Social Critique of the Judgment of Taste, London, Routledge, 2010.

${ }_{7}$ Slavoj Žižek, The Sublime Object of Ideology, London, Verso Books, 1989. 
adapting literary texts to other media, but also the complex cultural hierarchies that shape our reading of them.

In the following essay, I will argue that this transformation of media value constitutes a politics of adaptation that revolves around appealing to a desirable global elite audience through elaborate processes of branding and gentrification. In the first section, I introduce and unpack the term 'Quality TV' as a meta-genre that has shaped the recent development of what we might term 'cine-literary television.' The second part of this article will offer a critical reflection of how the creation of imaginary worlds relies on its own form of politics, which in the case of Game of Thrones involves the mapping out of a pseudo-medieval geopolitical landscape that relates back to an imagined global past. Then, in the third and final section, my article brings together these elements in its discussion of 'grittiness' and 'authenticity' as concepts that can be applied to better understand Game of Thrones as a particularly relevant case study that places 'Quality TV' within the cultural logic of gentrification.

\section{1. 'Quality television' and cine-literary culture}

As network audiences declined in the face of competition from the proliferation of cable and satellite channels in the 1980s, the networks became less concerned with attracting mass audiences and increasingly concerned with retaining the most valuable audiences: affluent viewers that advertisers were prepared to pay the highest rates to address. In other words, the compulsiveness of 'must see' television is designed to appeal to affluent, highly educated consumers who value the literary qualities of these programs, and they are used by the networks to hook this valuable cohort of viewers into their schedules.

The first and most important obstacle for the producers of Game of Thrones to overcome was the low-brow perception of the fantasy genre. Many television critics initially sneered at the notion that a premium cable network like HBO would include this type of genre material in their established 'Quality TV' brand, with the New York Times describing it as 'boy fiction patronizingly turned out to reach the population's other half ${ }^{8}$. But audiences and critics alike were soon won over, and Game of Thrones now stands as one of the most widely acclaimed series in HBO's current roster of programs, with its fourth season breaking the network's

${ }^{8}$ Ginia Bellafante, 'A Fantasy World of Strange Feuding Kingdoms', in The New York Times, April $4^{\text {th }}, 2011$. 
viewership record previously held by the final series of The Sopranos 9 .

A key element in the series' success has been its producers' successful negotiation of the text's relationship to its generic affiliation on the one hand, and its position within the format of premium cable 'Quality TV' on the other. This concept of 'Quality TV' is constructed around the notion of appealing to a particular audience with abundant disposable income, and has traditionally been organized around hybrid texts that combined familiar television formats with themes and aesthetics drawn from more celebrated sources such as the Hollywood gangster film, romantic comedy, and European arthouse cinema. Following the basic format established in the early 1980 s by production company MTM, HBO was the first cable TV company to foreground its programming's high art connections by emphasizing 'character development, structural complexity, reflexivity, [and] aesthetic innovation ${ }^{10}$ '. This formula ensured the critical success of series ranging from HBO's own The Sopranos (1999-2007) and Sex and the City (1998-2004) to Showtime hits like Homeland (2011- ) and Californication (2007-2014), all of which are designed to appeal primarily to premium cable's coveted audience of upper-middle class subscribers with abundant disposable income.

The 'quality TV' meta-genre should therefore be read primarily as a form of adaptation, successfully 'remediating ${ }^{11}$ ' the aesthetics of cinema on the one hand, and the narrative structure of the $19^{\text {th }}$-century realist novel on the other. But at the same time, television's strategic incorporation of elements from other media occurred within a context in which all narrative media were fully engaged in a complex process of technological and cultural convergence ${ }^{12}$. Jim Collins describes the resulting alignment between cinema and literature as a new kind of 'cine-literary culture,' allowing for 'an unprecedented interdependency of the publishing, film, and television industries, which can reach that "public at large" wherever it may be with ever greater proficiency ${ }^{13}$ '. The flattening out of former cultural hierarchies therefore results in an environment in which changing social practices alongside the increasing conglomeration of media industries has made the consumption of 'quality TV' a cine-literary

9 Tim Kenneally, 'Game of Thrones Becomes Most Popular Series in HBO's History', in The Wrap, June $5^{\text {th }}, 2014$.

${ }^{10}$ Jane Feuer, 'The MTM Style', in S. Feuer, P. Kerr and T. Vahimagi (eds.), MTM 'Quality Television', London, BFI, 1984, p. 34.

${ }^{11}$ Jay David Bolter and Richard Grusin, Remediation: Understanding New Media, Cambridge, MIT Press, 2000.

${ }^{12}$ Henry Jenkins, op. cit.

${ }^{13}$ Jim Collins, Bring On the Books for Everybody: How Literary Culture Became Popular Culture, Durham, Duke University Press, 2010, p. 33. 
experience that creates new value for corporate producers like HBO.

This appeal hinges on HBO's identity as a premium brand offering boutique programming, perpetually constructing for itself 'an air of selectivity, refinement, uniqueness, and privilege ${ }^{14}$ '. For $\mathrm{HBO}$ and other television producers in the post-network era, the careful development of this brand identity has relied on the way in which it 'offers consumers a place where it's okay to be transgressive with regard to mainstream television ${ }^{15}$ '. Premium cable's drama series tend to offer this kind of televisual transgression by including depictions of nudity, sex, and violence, alongside generous profanity, thus differentiating itself from 'normal' network TV drama and its traditional policy of offering 'least objectionable programming (LOP) ${ }^{16}$ '. These characteristics have become so institutionalized and predictable that the term 'Quality' in this context should be taken not so much as an actual qualitative distinction, but as identifying 'a set of generic traits that distinguishes a group identity ${ }^{17}$ '.

This group identity, spearheaded for over a decade now by HBO's corporate brand, distinguishes itself by offering what might be described as 'most objectionable programming,' but in ways that are experienced as literary rather than televisual, ground-breaking rather than gratuitous, challenging rather than accessible. Celebrated by enthusiastic audiences as complex texts that use the television medium to combine the production values and visual style of cinema with the narrative complexity of the $19^{\text {th }}$ century novel, 'Quality TV' has in recent years bestowed a bourgeois sense of respectability upon a medium all too frequently maligned by highbrow audiences:

HBO must continuously promote discourses of 'quality' and 'exclusivity' as central to the subscription experience. These discourses aim to brand not only $\mathrm{HBO}$, but its audience as well. In this manner, pay cable sells cultural capital to its subscribers, who are elevated above the riffraff that merely consume television, a medium long derided as base and feminizing in its unabashed

14 John T. Caldwell, Televisuality: Style, Crisis and Authority in American Television, New Brunswick, Rutgers University Press, 1995, p. 141.

15 Marc Leverette, 'Cocksucker, Motherfucker, Tits', in M. Leverette, B.L. Ott and C.L. Buckley (eds.), It's Not TV: Watching HBO in the Post-Television Era, New York, Routledge, 2008, [p. 123-51], p. 144.

${ }^{16}$ Robin Nelson, 'Quality TV Drama: Estimations and Influences Through Time and Space', in J. McCabe and K. Akass (eds.), Quality TV: Contemporary American Television and Beyond, London, Tauris, 2007, p. 39.

17 Sarah Cardwell, 'Is Quality Television Any Good?', in J. McCabe and K. Akass (eds.), Quality TV: Contemporary American Television and Beyond, New York, I.B. Taurus, 2007, [p. 19-34], p. 32 . 
embrace of consumerism ${ }^{18}$.

Described by some as 'The Sopranos meets The Lord of the Rings ${ }^{19}$ ', Game of Thrones combines the cinematic visual spectacle of pseudomedieval high fantasy with the tonal register of adult-oriented Quality TV, adapting what was generally viewed as an immature niche genre to HBO's upmarket brand identity. Commensurate with this seal of cultural respectability is the explicit identification of an author figure who is responsible for the text - which, in the case of Game of Thrones, is not only identified in the writerly persona of George R.R. Martin, but also in the series' celebrated duo of executive producers, David Benioff and Daniel B. Weiss. Their co-authorship of the television adaptation, which is emphasized throughout the series' promotional materials, reflects the historical development through which show runners and executive producers gained ever greater public prominence as celebrated creative forces, 'because their names proved more attractive to demographically desirable audiences than did the network brand ${ }^{20}$.

This foregrounding of author figures activates specific discourses of fidelity and literacy, and in a way that places 'a high premium on the kind of authorship more commonly associated with traditional art forms carrying high cultural kudos: theater, international art cinema, and literature $^{21}$. In the case of Game of Thrones, the series' systematic incorporation of brutal violence and explicit sex scenes thus functions not only to 'liberate television fiction from the laws governing established creative practices and writing styles ${ }^{22}$, as is by now customary for premium cable productions; it also adapts the fantasy genre in a way that makes it more attractive and accessible to a very particular and explicitly adult audience, thus dramatically increasing its commodity value.

Game of Thrones should therefore be seen as an adaptation in multiple senses: not only as a television show that adapts a series of novels, but also as the adaptation of an industrial framework that expands the existing parameters of what constitutes 'Quality TV' in the post-network

18 Avi Santo, 'Para-Television and Discourses of Distinction: The Culture of Production at HBO', in M. Leverette, B.L. Ott and C.L. Buckley (eds.), It's Not TV: Watching HBO in the PostTelevision Era, New York, Routledge, 2008 [p. 19-45], p. 20.

19 Sarah Hughes, “Sopranos Meets Middle-earth”: How Game of Thrones Took Over Our World', The Guardian, March 22 $2^{\text {nd }}, 2014$.

${ }^{20}$ Roberta E. Pearson, op. cit., p. 241.

${ }^{21}$ Janet McCabe and Kim Akass, 'It's Not TV, It's HBO's Original Programming: Producing Quality TV', in M. Leverette, B.L. Ott and C.L. Buckley (eds.), It's Not TV: Watching HBO in the Post-Television Era, New York, Routledge, 2008, [p. 83-94], p. 87.

${ }^{22}$ Ibid., p. 89. 
era. At the same time, the series has managed to re-articulate and reorganize key generic features of high fantasy and its audience. Premium cable appeals to its core viewers because it 'minimizes the value of popular television and popular culture in general while marketing and addressing seemingly non-televisual programs to upscale television audiences ${ }^{23}$ '. The development of Quality TV is also an intensely gendered form of cultural discourse:

if TV feminizes all who watch it, and feminization is linked to a loss of power and status brought about through the act of consumption, then HBO's brand offers to "re-mark" subscribers as "masculine," thus repositioning its audience as powerful bearers of cultural capital that is free from the commercialized trappings of regular television ${ }^{24}$.

This makes it irrelevant whether the actual audience is predominantly male or female: either way, the dispositif that defines the viewer's relationship to the medium has been changed from 'passive,' 'feminine' spectatorship to that of an 'active,' and therefore 'masculine' connoisseur.

\section{Topofocal Storytelling: Fantasy Maps and the Politics of World-Building}

The promotional material surrounding the first season of Game of Thrones generally emphasized the ways in which it departed from general preconceptions about the fantasy genre, most noticeably in the emphasis on complex, adult storytelling. One of the generic features of the fantasy genre that has been left intact both in Martin's novels and in the TV adaptation is the strong emphasis on the mapping of imaginary geographical spaces, as is so often the case with 'secondary worlds ${ }^{25}$ '. With many varieties of high fantasy literature, one is all but forced to keep the accompanying maps handy while reading, as one's understanding of the narrative is mostly predicated on the ability to follow the characters' trajectories through this fictitious geography. In many fantasy franchises devoted to the development of imaginary worlds, this emphasis on mapping out the diegetic environment shifts the audience's focus from the narrative's causal chain to the complex environment that sustains it,

23 Sudeep Dasgupta, 'Policing the People: Television Studies and the Problem of "Quality", NECSUS, Vol. 1, No. 1, Spring 2012.

${ }^{24}$ Avi Santo, op. cit., p. 34.

25 Mark J.P. Wolf, Building Imaginary Worlds: The History and Theory of Subcreation, London, Routledge, 2012. 
something Stefan Ekman refers to as a 'topofocal' - or place-centric approach, in which 'setting is as important as character and plot'26.

The books in the series include multiple maps of the lands of Westeros and the franchise's other notable imaginary areas, which prove to be essential in order to form a basic understanding of the narrative events. Similarly, the opening credits of the TV version present an animated rendition of this geographical map, offering the viewer helpful weekly reminders of the spatial relations between the story's key locations ${ }^{27}$. In addition, fan-made maps and highly detailed breakdowns of the series' various national histories and geographies have proliferated on the web, further emphasizing the crucial role played by the literal mapping of space in this fantasy environment ${ }^{28}$.

This obsession with spatio-temporal integrity is by no means unique to fantasy. One might say that the mapping out of multiple characters' trajectories through measurable time and space has been an organizing feature in narrative fiction from the early modern novel onwards: Robinson Crusoe (1719) and Pride and Prejudice (1813), perhaps the two most widely read and most frequently copied novels in the English literary tradition, are only the most obvious examples of a similarly obsessive textual mapping of characters in relation to coherent temporal and geographical coordinates. As David Harvey has noted in regard to this way of mapping out and thereby controlling space,

The Renaissance revolution in concepts of space and time laid the conceptual foundations in many respects for the Enlightenment project. What many now look upon as the first great surge of modernist thinking, took the domination of nature as a necessary condition of human emancipation. Since space is a 'fact' of nature, this meant that the conquest and rational ordering of space became an integral part of the modernizing project 29 .

26 While Ekman's study acknowledges that many fantasy books are published without accompanying maps, his empirical work as well as his own specialized engagement with the topic demonstrates quite vividly the commonly assumed equivalence between fantasy narratives and maps of imaginary lands. See Stefan Ekman, Here Be Dragons: Exploring Fantasy Maps and Settings, Middletown, Connecticut, Wesleyan University Press, 2013, p. 2.

${ }^{27}$ As the series moves through its yearly seasons, the animated map in the opening credits has changed to reflect the importance of new locations as well as changes to existing ones.

${ }^{28}$ See for example the interactive Google Map of Westeros created by fans (see Ben BeaumontThomas, 'Game of Thrones fans create an interactive map of Westeros... via Google Maps', in The Guardian: Radio \& TV Blog, April $\left.15^{\text {th }}, 2014\right)$, or the elaborate geological map created by a team of geologists and map designers at Stanford University (see Annalee Newitz, 'A Fantastically Detailed Geological History for Game of Thrones', http://iog.com/a-fantastically-detailedgeological-history-for-game-of-1561092800, April $8^{\text {th }}$, 2014).

${ }_{29}$ David Harvey, The Condition of Postmodernity, Malden, Blackwell Publishing, 1990, p. 249. 
The high fantasy genre and its insistent mapping of imaginary space is therefore all the more remarkable for the fact that its narratives are resolutely anti-modern, even as they rely so heavily on quintessentially modern organizations of space and time that produce what Harvey calls 'a homogenization and reification of the rich diversity of spatial itineraries and spatial stories,' while 'eliminating little by little all traces of the practices that produce it30'. Or, as Negri and Hardt would put it: 'Modernity replaced the traditional transcendence of command with the transcendence of the ordering function ${ }^{31}$ '. In other words, the kind of mapping so commonly associated with fantasy world-building automatically suggests a politics of conquest and imperialism, as the individual character's abilities to navigate these spaces become the default focus.

$20^{\text {th }}$-century modernist literature destabilized this early modern sense of spatio-temporal coherence, fracturing the integrity of space and time by its intensely subjective forms of representation ${ }^{32}$, and late $20^{\text {th }}$ century postmodernism represented an even more radical challenge to our ability to develop what Jameson describes as a cognitive map of our environment 33 . The contemporary popularity of high fantasy may therefore be understood in part at least as a response to the genre's dialectical tension between the pre-modern worlds they tend to articulate, and their fundamentally modern ways of organizing and representing them.

The most problematic aspect of this preoccupation with the mapping out of geopolitical spaces is the way this naturalizes a fundamentally political dichotomy between a Western 'us' and nonWestern 'Other,' occupying 'a specific place in a spatial order that was ethnocentrically conceived to have homogeneous and absolute qualities 34 '. The way in which these maps organize the narrative's physical and conceptual space into a basic binary distinction between the civilized world of Westeros and the more mystical, dangerous, and generally more primitive areas to the east and south reflect a very specific tradition of the high fantasy genre that articulates a distinctly Eurocentric perspective35. Visits to the foreign lands surrounding the central kingdoms of Westeros

${ }^{30}$ Ibid., p. 253.

${ }^{31}$ Antonio Negri and Michael Hardt, Empire, Cambridge, Massachusetts \& London, England, Harvard University Press, 2000, p. 88.

$3^{2}$ David Harvey, op. cit., p. 10-38.

33 Fredric Jameson, 'Cognitive Mapping', in C. Nelson and L. Grossberg (eds.), Marxism and the Interpretation of Culture, Champaign, University of Illinois Press, 1990, p. 347-60.

34 David Harvey, op. cit., p. 252.

35 One central irony of the series is that the larger threat to the inhabitants of Westeros actually comes from the North, beyond The Wall. 
demonstrate the conventional forms of Orientalism, as both the nonWestern geographies and their inhabitants are portrayed as mysterious, unchanging, backwards, and treacherous. Therefore, although Game of Thrones does not entirely duplicate Tolkien's more rampant xenophobia, the series' structural distinction between a Western 'us' and a mystical, foreign 'other' does clearly re-articulate the genre's traditional Eurocentric construction of global geopolitics.

In the series, this distinction is made most obvious in the plot strand that follows the exiled Daenerys Targaryen, one of several candidates who seek to claim the Iron Throne and become the single ruler of Westeros and its seven kingdoms. She has spent all of her time in the five novels that have been completed as of spring 2014, and the four seasons of the television series, in the lands of Essos, located to the east and across the sea from the franchise's central kingdoms. As Daenerys moves around the larger but far more thinly populated lands of Essos, she encounters several different cultures, many of which exist either as tribal hunter-gatherers (e.g. the Dothraki) or as vaguely Orientalist city-states (e.g. Qarth). What all the lands outside of Westeros have in common is that they are presented as more primitive and implicitly unchanging than the more advanced Seven Kingdoms. And while these cultures are not presented with the same degree of callous disdain that Tolkien famously demonstrated for any peoples from outside the borders of Middle-earth, the overwhelmingly Eurocentric perspective that organizes the series' topofocal world couldn't be more obvious: the central 'game of thrones' illustrates vividly how the central dramatic conflict in the franchise revolves around gaining control of the proto-European area of Westeros, with all the more primitive lands of decidedly secondary importance.

The series' racial politics in relation to its spatial organization is even more pronounced in the television adaptation, where the 'Common Tongue' in Westeros is English ${ }^{36}$, while the inhabitants of Essos speak in made-up languages like 'High Vallyrian,' which are subtitled. The result is that the distinction between the 'normal' space of the kingdoms of Westeros, as a fantastical hybrid that fuses the British isles with continental Europe, systematically privileges the Eurocentric perspective over its

${ }^{36}$ Tellingly, characters who live in 'the North' of Westeros have (mostly) Northern-English or Scottish accents, like the Sheffield-born actor Sean Bean, while those in the more southern capital of King's Landing have fancier-sounding southern accents (see Brian Wheeler, 'Why are Fantasy World Accents British?', in BBC News, March $\left.30^{\text {th }}, 2012\right)$. Characters from even further south in the seven kingdoms, such as those from the kingdom of Dorne, speak English with vaguely mediterranean-sounding accents, and have cast actors like the Chilean-American actor Pedro Pascal and the Indian-Swiss actress Indira Varma. 
available alternatives. While the series does go out of its way to cast its characters in such a way that none of these more 'primitive' lands can be directly related to a single real-world equivalent, the overall effect strongly reinforces the Orientalist conceit that projects a radical otherness onto the East 37 .

The politics of this patronizing representation of non-Western spaces becomes most painfully obvious in the extended subplot of Daenerys's quest to liberate the slaves in several city-states in the southern region of Essos, located around Slaver's Bay. The motif of an enlightened 'white messiah' liberating non-Western cultures from their backward ways has a long history in Western literature and cinema, with countless examples ranging from Rudyard Kipling's 'White Man's Burden' (1899) to Steven Spielberg's Indiana Jones and the Temple of Doom (1984). The fact that Daenerys happens to be a female white messiah whose naïve actions produce unexpected complications should not be interpreted as especially progressive in terms of the series' fundamental Orientalism: the key point is that the civilizations outside of Westeros, populated by people of color, are once again shown to be unable to control their own destinies, requiring the intervention of a 'more advanced' outsider. In spite of Game of Thrones' aesthetic sophistication, narrative complexity, and adult sensibilities, the way it therefore maps out its world still tends to fall in line with a reactionary form of politics that privileges the Western perspective while applying generic but nevertheless egregious stereotypes to its imagined, non-Western 'other. ${ }^{38}$ '

\section{Gentrification and the construction of 'authenticity'}

The mapping out of difference within the diegetic world of Game of Thrones reflects and enhances the current transformation of television as an important bearer of cine-literary cultural capital. As described above, the series' appeal to its largest audience derived not from its relationship to its literary source, which for most viewers formed an obstacle rather than an attraction. While the publicity campaign made good use of the novels' readership as online 'influencers' whose extensive use of social media

37 Edward Saïd, Orientalism: 25th Anniversary Edition, New York, Vintage, 2004.

38 While some may argue that Game of Thrones depicts many of its Western characters negatively, there is an obvious difference between portraying individual characters as good or evil, or rendering judgment on an entire culture. This franchise clearly engages in the latter, especially in its depiction of non-Western countries that have not yet 'developed beyond' the slave trade, or in the show-runners' decision to invent non-European-sounding languages for nations outside Westeros. 
provided the first season with positive 'buzz', most promotional materials distributed by HBO foregrounded the show's complexity, its maturity, and its novelty. Paradoxically, the series' respectability came to rely on familiar 'Quality TV' ingredients like its harsh violence, its uncompromising cynicism, and its frank depiction of sexual acts. The class-based prejudice that has legitimized this practice implies that pay cable consumers can handle graphic language, sex, and violence in a more thoughtful and productive way than broadcast viewers ${ }^{39}$.

In its depiction of sex and (female) nudity, the series pays lip service to the books' cynical perspective on sex and the female body as a form of currency in its pseudo-medieval society. But more than this, several critics have pointed out that the show's constant flaunting of naked female bodies, quickly and astutely dubbed 'sexposition' by blogger and cultural critic Myles McNutt ${ }^{40}$, has more to do with the kind of audience the series is addressing, and its obvious attempts to rid itself of those genre elements that have limited high fantasy to a primarily fan-driven audience. Indeed, 'the show's softly lit and erotic staging of any scene involving a naked woman evokes Playboy of the 1960 s and '70s more than it underscores sexual politics or a culture of violence ${ }^{41}$. At the same time, the series makes sure that it caters to progressive tastes and female viewers by including many women characters in non-traditional gender roles, including Brienne, Arya, and Daenerys.

The inclusion of such sexually explicit material simultaneously adapts fantasy as a genre that is appropriate for an adult audience. Just as cultures of fandom are derogatorily viewed as immature or even childish, many of the key texts in popular cultures of fandom are marked by a peculiarly chaste or even puritanical approach to nudity and sexuality. Star Wars, The Lord of the Rings, Harry Potter, and many other key fan-driven franchises in the broad 'popular fantasy' genre display little interest in sexuality or eroticism, with romantic relationships defined primarily by fairy-tale concepts of chivalric love and extremely chaste depictions of romantic relationships. Taken together with the fantasy genre's prominent association with role-playing, flat characters, and fantastical creatures, the general perception has been one of a pervasive and perhaps even

39 Deborah L. Jaramillo, 'The Family Racket: AOL Time Warner, HBO, The Sopranos, and the Construction of a Quality Brand', in Journal of Communication Inquiry, Vol. 26, No. 1, 2002 [p. 59-75], p. 66.

$4^{\circ}$ See Valerie E. Frankel, Women in Game of Thrones: Power, Conformity and Resistance, Jefferson, McFarland, 2014, p. 7.

${ }^{41}$ Anna Holmes, 'Skin is Wearing Thin on HBO's Game of Thrones', in The Washington Post, April $27^{\text {th }}, 2012$. 
fundamental lack of maturity. And while the breakthrough success of Peter Jackson's filmed Tolkien adaptations has certainly contributed to the genre's wider acceptance among mainstream audiences, the franchise's depiction of Middle-earth did little to alter the larger sense that the genre thrived on childish spectacles of good versus evil. A key aspect of the transformation of the fantasy genre orchestrated by Game of Thrones is therefore its deliberate appeal to an explicitly upscale and (crucially) adult audience, which was accomplished primarily through the established aesthetic paradigms of Quality TV.

These elements bestow upon the show a critical sense of discursive authenticity that aligns itself with what sociologist Sharon Zukin has described as the cultural logic of gentrification. In her book Naked City: The Death and Life of Authentic Urban Places (2010), she describes gentrification as a hegemonic cultural process in which a political and economic elite continuously seeks out both physical spaces and (sub)cultural practices that are specifically associated with a 'gritty' sense of authenticity:

Critics praised gritty novels, plays, and art for their honest aesthetic qualities, their ability to represent a specific space and time, and identified 'gritty' with a direct experience of life in the way that we have come to expect of authenticity. ... Today the use of 'gritty' in the media depicts a desirably synergy between underground cultures and the creative energy they bring to both cultural consumption and real estate development, not as an alternative to but as a driver of the city's growth ${ }^{4}$.

Game of Thrones' discursive authenticity as an example of the cultural logic of gentrification resides not only in the many paratextual reassurances that the show is faithful to its literary source. It is also and perhaps even more visible in its uncompromising dedication to premium cable's familiar kind of 'most objectionable programming' involving sex and violence. While distancing itself from popular perceptions of the supposedly infantile fantasy genre, Game of Thrones offers value to those 'hipsters and gentrifiers' who continuously seek out novel but crucially 'authentic' experiences43, and who of course also happen to make up HBO's most desirable audience.

The show's tendency to court controversy therefore makes more sense once we perceive it from this perspective of gritty, uncompromising

$4^{2}$ Sharon Zukin, Naked City: The Death and Life of Authentic Urban Places, Oxford, Oxford University Press, 2010, p. 53

43 Ibid., p. 7. 
authenticity, and the way it continuously distinguishes HBO's brand identity from 'normal' network television. As the series has developed throughout its first four seasons, it has in fact adapted the most violent and controversial moments from the novels by making them even more extreme than the already somewhat notorious source texts 44 . For instance, in the third-season episode that adapts the 'Red Wedding' chapter from the novel A Storm of Swords (2000), the mass murder that takes place onscreen involves not only the grisly deaths of popular leading characters Robb and Catelyn Stark, but also that of Robb's fiancée, whose pregnant belly is graphically stabbed several times before her throat is slit. The showrunners thus made the scene not only as graphically violent as possible, but adapted it for television in a way that made an already grisly sequence a great deal more upsetting and controversial, resulting in a great deal of desirable media attention that once again emphasized the show's 'gritty' and 'uncompromising' authenticity.

This moment and others like it demonstrate clearly that the traditional logic of film and television adaptations, in which the most potentially offensive elements are either removed or softened, finds its opposite in the cultural logic of gentrification and its politics of adaptation. The creation of value in this context hinges on the hegemonic appropriation and adaptation of subcultures and genres in ways that are experienced as overwhelmingly 'gritty' and 'authentic.' But while their Quality TV aesthetics align such offerings with recognizably branded commodities that hold enormous value for 'distinguished' viewers, the ideological organization of the franchise's story-world articulates the same kind of politics that underlies global processes of gentrification.

Much in the same way that AMC's popular TV adaptation of the comic book series The Walking Dead (2010-) has made the zombie genre accessible to a new audience, Game of Thrones has played a key role in the gentrification of the fantasy genre. While carefully working to remain inclusive towards the fan cultures that have traditionally sustained such texts, the HBO adaptation makes Martin's story-world accessible to a 'quality' audience that does not define itself in terms of fandom. Instead, high-culture categories of authorship, novelistic narrative complexity,

44 In the fourth-season episode 'Oathkeeper,' the transformation of an already-incestuous sex scene between Jaime and Cersei that was consensual in the book was dramatized as a rape scene in the series, an adaptive choice that follows the same logic but (for once) seemed to overreach in its attempt to be as 'gritty' as possible: it resulted in a great deal of negative criticism, which at the same time of course also brought more free publicity to the franchise as a form of 'mature and edgy' fantasy. 
psychological realism, and adult-oriented scenes of sex and violence connect to a larger discourse of innovative quality television that is innovative and 'edgy' in ways that remain tasteful to bourgeois viewers.

But while some of the most noticeable characteristics of traditional fantasy fiction have been tweaked or altered to adapt to the show's envisioned audience, Game of Thrones' rewriting of genre conventions leaves the most ideologically problematic building blocks largely intact: while the show resists the traditional Manichean structure of high fantasy, its larger plot still revolves around the concept of a monstrous exterior threat to its central proto-European geography; while the genre's most rampant xenophobic tendencies are at the very least tempered, the governing framework of Orientalist prejudice and racist assumptions is left intact; and even as the series' narrative critiques institutionalized sexism, it continuously fills up the screen with naked female bodies subjected to the male gaze. The franchise's success amongst upscale audiences can therefore be related more convincingly to cosmetic changes that bestow prestige on a disreputable genre than with any substantial attempts to address the reactionary ideological premises that ultimately continue to delimit the high fantasy genre.

\section{Bibliography}

Beaumont-Thomas Ben, 'Game of Thrones fans create an interactive map of Westeros... via Google Maps', The Guardian: Radio \& TV Blog, April $15^{\text {th }}, 2014$.

Bellafante Ginia, 'A Fantasy World of Strange Feuding Kingdoms,' The New York Times, 14 April 2011.

Bolter Jay David, GRUsIn Richard, Remediation: Understanding New Media, Cambridge, MIT Press, 2000.

BourdiEu Pierre, Distinction: A Social Critique of the Judgment of Taste, London, Routledge, 2010.

Caldwell John T., Televisuality: Style, Crisis and Authority in American Television, New Brunswick, Rutgers University Press, 1995.

CARDwEll Sarah, 'Is Quality Television Any Good?', in J. McCabe and K. Akass (eds.), Quality TV: Contemporary American Television and Beyond, 
New York, I.B. Taurus, 2007, p. 19-34.

Collins Jim, Bring On the Books for Everybody: How Literary Culture Became Popular Culture, Durham, Duke University Press, 2010.

Dasgupta Sudeep, 'Policing the People: Television Studies and the Problem of “Quality”', NECSUS, Vol. 1, No.1, Spring 2012.

EKMAN Stefan, Here Be Dragons: Exploring Fantasy Maps and Settings, Middletown, Connecticut, Wesleyan University Press, 2013.

EDGERTON Gary R., JonEs Jeffrey P., The Essential HBO Reader, Lexington, University of Kentucky Press, 2009.

FEuer Jane, 'The MTM Style', in S. Feuer, P. Kerr and T. Vahimagi (eds.), MTM 'Quality Television', London, BFI, 1984.

Frankel Valerie E., Women in Game of Thrones: Power, Conformity and Resistance, Jefferson, McFarland, 2014.

HaRvey David, The Condition of Postmodernity, Malden, Blackwell Publishing, 1990.

Holmes Anna, 'Skin is Wearing Thin on HBO's Game of Thrones', in The Washington Post, April 27 2012.

HuGHEs Sarah, “Sopranos Meets Middle-earth”: How Game of Thrones Took Over Our World', The Guardian, March 22d, 2014.

JAMEson Fredric, 'Cognitive Mapping', C. Nelson and L. Grossberg (eds.), Marxism and the Interpretation of Culture, Champaign, University of Illinois Press, 1990, p. 347-60.

JARAMillo Deborah L., 'The Family Racket: AOL Time Warner, HBO, The Sopranos, and the Construction of a Quality Brand', Journal of Communication Inquiry, Vol. 26, No. 1, 2002, p. 59-75.

JEnkins Henry, Convergence Culture: Where Old and New Media Collide, New York, New York University Press, 2006. 
JoHnson Catherine, 'Tele-branding in TVIII: The network as brand and the programme as brand', New Review of Film and Television Studies, Vol. 5, No. 1, 2007, p. 5-24.

KenneAlly Tim, 'Game of Thrones Becomes Most Popular Series in HBO's History', The Wrap, June $5^{\text {th }}, 2014$.

LEVERETTE Marc, 'Cocksucker, Motherfucker, Tits', in M. Leverette, B.L. Ott and C.L. Buckley (eds.), It's Not TV: Watching HBO in the Post-Television Era, New York, Routledge, 2008, p. 123-51.

McCABE Janet, AKASs Kim, 'It's Not TV, It's HBO’s Original Programming: Producing Quality TV', in M. Leverette, B.L. Ott and C.L. Buckley (eds.), It's Not TV: Watching HBO in the Post-Television Era, New York, Routledge, 2008, p. 83-94.

MitTell Jason, Genre and Television: From Cop Shows to Cartoons in American Culture, Florence, Psychology Press, 2004.

NEgri Antonio, HARDT Michael, Empire, Cambridge, Massachusetts \& London, England, Harvard University Press, 2000.

NeLSON Robin, 'Quality TV Drama: Estimations and Influences Through Time and Space', in J. McCabe and K. Akass (eds.), Quality TV: Contemporary American Television and Beyond, London, Tauris, 2007.

NEwITz Annalee, 'A Fantastically Detailed Geological History for Game of Thrones', http://iog.com/a-fantastically-detailed-geological-history-forgame-of-1561092800, April 8 ${ }^{\text {th }}, 2014$.

Pearson Roberta E., "Lost in Transition: From Post-Network to PostTelevision", J. McCabe and K. Akass (eds.), Quality TV: Contemporary American Television and Beyond, London, Tauris, 2007.

SAÏD Edward, Orientalism: 25th Anniversary Edition, New York, Vintage, 2004.

SANTo Avi, 'Para-Television and Discourses of Distinction: The Culture of Production at HBO', in M. Leverette, B.L. Ott and C.L. Buckley (eds.), It's Not TV: Watching HBO in the Post-Television Era, New York, Routledge, 2008, p. 19-45. 
WHEELER Brian, 'Why are Fantasy World Accents British?', BBC News, March $30^{\text {th }}, 2012$.

WoLF Mark J.P., Building Imaginary Worlds: The History and Theory of Subcreation, London, Routledge, 2012.

ŽıžEK Slavoj, The Sublime Object of Ideology, London, Verso Books, 1989.

Zukin Sharon, Naked City: The Death and Life of Authentic Urban Places, Oxford, Oxford University Press, 2010.

\section{The author}

Dan Hassler-Forest currently works as an assistant professor of film and literature based in the English department of the University of Amsterdam, and is a frequent public lecturer on contemporary film, adaptation theory, animation and digital cinema, urban studies, and theoretical approaches to popular culture. He also teaches at Amsterdam University College. He wrote Capitalist Superheroes: Caped Crusaders in the Neoliberal Age (Zero Books, 2012) on the Bush-era superhero movie genre. All of his work is informed by a critical approach to commodity culture and globalized capitalism, with a special focus on the political and ideological implications of fantasy genres. 